\title{
Wybrane zadania samorządu gminnego w Polsce w zakresie ochrony środowiska w kontekście integracji europejskiej
}

\author{
GRAŻYNA GADOMSKA \\ DR
} ADIUNKT AH

Wydział Humanistyczny Akademii Humanistycznej im. A. Gieysztora w Pułtusku Filia Akademii Finansów i Biznesu Vistula e-mail: ggadomska@poczta.onet.pl

Słowa kluczowe środowisko, ochrona środowiska, zadania samorządu gminnego

Abstrakt Środowisko pozostaje w stałej relacji z człowiekiem, który korzysta z jego zasobów. W artykule przedstawiono specyfikę zadań samorządu gminnego w zakresie ochrony środowiska w kontekście szeroko rozumianych procesów integracyjnych. W tym celu dokonano analizy literatury przedmiotu oraz przepisów prawa regulujących działania gminy. Przeprowadzono analizę wybranych zadań samorządu gminnego w zakresie ochrony środowiska. Realizacja strategicznych celów w tym obszarze jest bardzo ważnym wyzwaniem i determinantą rozwoju lokalnego. Zadania realizowane przez władze państwowe i lokalne są podstawa skuteczności działań na rzecz ochrony środowiska.

Selected tasks of the local government in Poland in the field of environmental protection in the context of European integration

Keywords environment, environmental protection, task of local government

Abstract The environment is in constant relationship with the man who uses his resources. The article presents the specificity of municipal self-government tasks in the field of environmental protection in the context of broadly understood integration processes. To achieve this goal, an analysis of the literature on the subject and legal provisions regulating the activities of the commune was made. An analysis of selected municipal self-government tasks in the field of environmental protection was carried out. The implementation of strategic goals in this area is a very important challenge and determinant of local development. The tasks implemented by state and local authorities are the basis for the effectiveness of environmental protection measures. 


\section{Wprowadzenie}

We współczesnym świecie zagrożenie ekologiczne stało się jednym z najczęściej uświadamianych zagrożeń - w wymiarze lokalnym, ponadlokalnym, i międzynarodowym, na co wpływają zarówno dynamiczne zmiany cywilizacyjne, gospodarcze, postęp technologiczny, jak i postępujące procesy globalizacji. Zmiany te bezpośrednio i pośrednio określają istotę i potrzebę ochrony środowiska, które zaczęło ulegać degradacji.

Unia Europejska jako organizacja międzynarodowa traktuje priorytetowo kwestię szeroko rozumianej ekologii. Polska, jako kraj członkowski UE, podjęła realizację wielu zobowiązań dotyczących prowadzenia odpowiedzialnej polityki ekologicznej, w odpowiedzi na rosnące zagrożenia ekologiczne. Obszar ten stał się jednym z najważniejszych ze względu na problemy związane z gospodarką odpadami, ochroną zdrowia obywateli, dbaniem o zapewnienie czystości wód i powietrza. Zadaniem państwa jest zapewnienie obywatelom prawa do życia i funkcjonowania w zdrowym i bezpiecznym środowisku. Polska podjęła współdziałanie z rządami europejskimi polegające na stosowaniu ściśle określonych ustaw i regulacji prawnych (Stawarska, 2001, s. 96-99). Europejskie regulacje określają współpracę miedzy innymi w zakresie zapobiegania katastrofom ekologicznym oraz klęskom żywiołowym, na występowanie których wpływa np. nadmierna eksploatacja środowiska naturalnego, niszczenie ekosystemów przez odpady toksyczne. Ochrona środowiska jest dla współczesnych społeczeństw problematyką obejmującą zmiany klimatu, ochronę powietrza, wód i mórz, gospodarkę odpadami. Negatywne skutki zanieczyszczenia środowiska dostrzegane są zarówno na poziomie globalnym, jak i lokalnym. Podstawą zarządzania środowiskiem w skali globalnej jest dlatego zarządzanie na poziomie lokalnym. Zadania w zakresie ochrony środowiska mają charakter interdyscyplinarny. Ich realizacja wymaga powiązania aspektów fizycznych, chemicznych, społecznych, technologicznych, politycznych, ekonomicznych i prawnych. Kwestie środowiskowe regulowane są na trzech poziomach - globalnym, regionalnym (system prawa UE), krajowym (Karski, 2011, s. 86). Zadania w zakresie ochrony środowiska stawiane przed samorządem gminnym stanowią podstawowy obszar działań. Celem artykułu jest przedstawienie wybranych zadań samorządu terytorialnego gminy w Polsce w zakresie ochrony środowiska. W realizacji celu zastosowano metodę prawno-instytucjonalną, służącą analizie regulacji krajowego porządku prawnego. Głównym założeniem jest pogląd, że działania gminy na rzecz ochrony środowiska wynikają z nowelizowanych regulacji ustawowych, które zobowiązują do przyjmowania odpowiedzialności za obecny i przyszły stan zasobów środowiska.

\section{Pojęcie i istota ochrony środowiska}

Pojęcie środowisko jest wieloznaczne. Obejmuje szeroko rozumiane otoczenie, w tym warunki socjalne, ekonomiczne, rozwojowe, lecz przede wszystkim warunki środowiska naturalnego. Termin „środowisko” często stosowany jest wraz z określeniami „środowisko przyrodnicze”, środowisko geograficzne”, ,środowisko człowieka”. W tekście Deklaracji Sztokholmskiej (Deklaracja Sztokholmska, 1972) zbiór elementów składających się na środowisko człowieka to zasoby naturalne (powietrze, woda, flora, fauna), warunki życia i pracy, edukacja, nauka 
i zasoby cywilizacyjne, zabezpieczające potrzeby egzystencjalne człowieka oraz możliwości rozwoju społecznego, intelektualnego, moralnego i duchowego. W Deklaracji zawarte jest ponadto ustalenie mówiące o tym, że sprawy międzynarodowe dotyczące ochrony i poprawy stanu środowiska winny być podejmowane w duchy współpracy wszystkich krajów. Współpraca ta, z uwzględnieniem interesów wszystkich państw, oparta na wielostronnych lub dwustronnych porozumieniach ma fundamentalne znaczenie w zapobieganiu narażania środowiska na ujemne skutki wynikające z działalności człowieka w różnych dziedzinach. Ustalenia te dotyczą obecnego i przyszłych pokoleń oraz nakładają na rządy państw obowiązek dbałości o środowisko. W art. 3 pkt 13 podstawowego aktu prawnego - ustawy z 27 kwietnia 2001 roku Prawo ochrony środowiska, pojęcie ochrony środowiska definiowane jest jako podjęcie lub zaniechanie działań, umożliwiających zachowanie lub przywracanie równowagi przyrodniczej. Ochrona ta polega w szczególności na: racjonalnym kształtowaniu środowiska i gospodarowaniu zasobami środowiska zgodnie z zasadą zrównoważonego rozwoju; przeciwdziałaniu zanieczyszczeniom; przywracaniu elementów przyrodniczych do stanu właściwego (Ustawa, 27.04.2001). Ochrona środowiska oznacza zatem działania człowieka skoncentrowane na zabezpieczeniu środowiska dla kolejnych pokoleń tak, by możliwa była ich bezpieczna egzystencja. Kraje UE, w tym Polska, poświęcają coraz więcej uwagi zagrożeniom ekologicznym w ramach polityki bezpieczeństwa ekologicznego określanego jako bezpieczeństwo środowiskowe. Polska zadeklarowała współdziałanie z rządami europejskimi w ramach realizacji programów ekologicznych oraz wdrażanie unijnych regulacji prawnych (Stawarska, 2001, s. 99).

Istota bezpieczeństwa jest wyrażana brakiem zagrożenia. Świadomościowy odbiór zagrożeń oraz ich wartościowanie przez poszczególne jednostki lub grupy jest zależny od indywidualnej wrażliwości i subiektywnych ocen, co niewątpliwie wpływa na relacje między ludźmi, grupami społecznymi, wspólnotami i państwami (Mieteń, 2014, s. 32). Wśród wielu rodzajów bezpieczeństwa, z punktu widzenia państwa, ale przede wszystkim społeczeństwa i obywateli wyróżniane jest bezpieczeństwo publiczne odnoszące się między innymi do miejsca zamieszkania, pracy i nauki, miejsc publicznych (np. parku), sytuacji klęsk żywiołowych i kryzysowych. Bezpieczeństwo jest priorytetem polityki wewnętrznej państwa i najwyższą wartością społeczną, warunkującą bezpieczeństwo zdrowia i życia obywateli, a także gwarantującą nienaruszalność ich mienia. Bezpieczeństwo publiczne może zostać zakłócone przez człowieka i nosić wówczas znamiona przestępstwa lub wykroczenia, bądź zakłócone przez siły natury (Szela, 2013, s. 164). W ujęciu E. Ury bezpieczeństwo publiczne w znaczeniu materialnym można rozumieć taki:

stan w którym ogółowi obywateli nie grozi żadne niebezpieczeństwo, niezależnie od tego, jakie by było jego źródło. Może więc odnosić się to do niebezpieczeństw będących wynikiem klęski żywiołowej, katastrofy, epidemii, bądź innych zjawisk stanowiących zagrożenie dla życia, zdrowia, mienia obywateli lub mienia publicznego (Ura, 2003).

Działalność instytucji UE skoncentrowana jest na wypracowywaniu umów skutkujących rozwiązaniami służącymi ochronie środowiska naturalnego. Polska zobowiązała się do respektowania prawa wspólnoty europejskiej jako prawa nadrzędnego w stosunku do prawa krajowego. Priorytetem działań jest przede wszystkim zapobieganie emisji zanieczyszczeń do środowiska. Znajdują tu zastosowanie traktaty założycielskie (Bylicki, 2014, s. 186-199), w tym Traktat 
o funkcjonowaniu Unii Europejskiej, a następnie ustawy, dyrektywy i rozporządzenia. Cele i zasady europejskiego wymiaru ochrony środowiska skoncentrowane są na zapobieganiu, w miarę możliwości, na unieszkodliwianiu zanieczyszczeń dzięki priorytetowemu wdrażaniu tzw. interwencji u źródła i zapewnianie rozsądnej gospodarki zasobami naturalnymi w myśl zasady ,zanieczyszczający płaci”, zasady zapobiegania zanieczyszczeniom oraz zasady przezorności. Zintegrowane podejście do ochrony środowiska polega między innymi na zapobieganiu emisjom do powietrza, środowiska wodnego i gleby, z uwzględnieniem gospodarki odpadami (Ciechanowicz-McLean, 2015, s. 26).

\section{Zadania gminy w dziedzinie ochrony środowiska}

Władze państw członkowskich są zobowiązane do wdrażania i przestrzegania prawa UE dotyczącego ochrony środowiska. Podstawą ustalania zadań i celów polityki ekologicznej jest Konstytucja Rzeczypospolitej Polskiej z 1997 roku, w której z art. 86 wynika prawny obowiązek dbałości o stan środowiska, przestrzegania przepisów związanych z ochroną przyrody oraz wdrażania środków prewencyjnych, których celem jest unikanie zagrożenia ekologicznego. Stanowi tym samym zobowiązanie do zapewniania bezpieczeństwa ekologicznego rozumianego jako „taki stan ekosystemu, w którym nie występuje ryzyko zakłóceń jego elementów albo jest ono niewielkie” (Kasperek, 2014, s. 69). Pojęcie „bezpieczeństwo ekologiczne” oraz „bezpieczeństwo środowiskowe" stosowane są często synonimicznie. W teorii bezpieczeństwa termin ten definiowany jest najczęściej jako:

stan uzyskany w rezultacie uwzględniania wielu uwarunkowań chroniących człowieka i środowisko oraz takie kształtowanie stosunków naturalnych i społecznych w biosferze Ziemi, które tworzy właściwe warunki życia dla całej ludzkości, nie podważając zarazem podstaw życia na naszej planecie, głownie poprzez podejmowanie i realizację koncepcji zrównoważonego rozwoju (Borkowski, 2017, s. 23).

Z perspektywy koncepcji bezpieczeństwa narodowego, zagadnienie ochrony środowiska utożsamiane z problematyką bezpieczeństwa ekologicznego (Ciszek, 2017, s. 119) zawarte jest w nowelizowanych strategiach bezpieczeństwa narodowego RP. W Strategii Bezpieczeństwa Narodowego z 2014 roku ochrona środowiska określona jest jako jeden z pozamilitarnych aspektów bezpieczeństwa państwa. Cele strategiczne obejmują między innymi zapewnienie rozwoju potencjału społecznego i gospodarczego państwa ze szczególnym uwzględnieniem ochrony środowiska naturalnego, warunków życia i zdrowia ludności. Nowelizacje dokumentu podejmowano w związku z integracją Polski z Unią Europejską i członkostwem Polski w NATO. Dzięki temu kwestie ekologiczne zajęły w dokumencie ważne miejsce, zostały powiązane z zagadnieniem zrównoważonego rozwoju i korespondują z regulacją art. 74 Konstytucji RP. Podkreśla to również zapis art. 68 Konstytucji RP, w którym wskazany jest obowiązek władz publicznych dotyczący ochrony środowiska, a także prawo do ochrony zdrowia, które władze publiczne zapewniają przez zwalczanie chorób epidemicznych i zapobieganie negatywnym dla zdrowia skutkom degradacji środowiska. Jednocześnie państwo zobowiązane jest do szerokiego 
informowania o stanie i ochronie środowiska oraz wspierania obywateli w działaniach na rzecz środowiska (Konstytucja RP, 1997). Krajowa polityka ekologiczna to działania państwa, samorządów terytorialnych i podmiotów gospodarczych odpowiedzialnych za ochronę środowiska. Polityka ta wymaga kształtowania świadomości ekologicznej na poziomie jednostki i grup społecznych przez edukację ekologiczną prowadzoną na wszystkich etapach kształcenia.

Samorząd terytorialny jest współuczestnikiem w sprawowaniu władzy publicznej, realizującym wykonawcze funkcje państwa, kierującym się dobrem wspólnym odnoszonym do interesów społeczności lokalnej (Konstytucja RP, 1997). Realizując zadania własne i zlecone, na podstawie ustawy lub porozumienia z administracją rządową, zabezpiecza podstawowe potrzeby obywateli. Poszczególne zadania i kompetencje w zakresie ochrony środowiska, realizowane na terytorium gminy, zostały skierowane głównie do wójta/burmistrza/prezydenta miasta. W myśl unormowania zawartego w art. 4 ust.1 ustawy o samorządzie gminnym są to zadania własne gminy, w tym obejmujące między innymi sprawy: ochrony środowiska i przyrody oraz gospodarki wodnej; gminnych dróg, ulic, mostów, placów oraz organizacji ruchu drogowego, usuwania i oczyszczania ścieków komunalnych, utrzymania czystości i porządku oraz urządzeń sanitarnych, wysypisk i unieszkodliwiania odpadów komunalnych; porządku publicznego i bezpieczeństwa obywateli oraz ochrony przeciwpożarowej i przeciwpowodziowej, w tym wyposażenia i utrzymania gminnego magazynu przeciwpowodziowego. Kompetencje organu wykonawczego gminy w zakresie zwykłego korzystania ze środowiska przez osoby fizyczne niebędące przedsiębiorcami, a także zasady ochrony środowiska i warunki korzystania z jego zasobów z uwzględnieniem wymagań zrównoważonego rozwoju obejmują warunki wprowadzania substancji lub energii do środowiska, koszty korzystania ze środowiska, obowiązki organów administracji, odpowiedzialność i sankcje (Ustawa, 13.04.2018, art. 1 ust. 1, art. 17). Według ustawy o samorządzie gminnym zasada zrównoważonego rozwoju oznacza zespolenie działań W sposób sprzyjający zachowaniu równowagi przyrodniczej. W UE zasada zrównoważonego rozwoju jest naczelną zasadą rozwoju gospodarczego, ochrony środowiska i polityki społecznej i obejmuje działania na poziomie państwa, regionu, samorządu lokalnego, przedsiębiorców, społeczeństwa obywatelskiego .Realizacja tych jest niewątpliwie związana z zadaniami własnymi samorządu terytorialnego, jednak nadanie tym zadaniom charakteru lokalnego nie wyklucza ich z kategorii zadań ogólnospołecznych. Zadania powierzone i rozwiązywane przez organy na szczeblach regionalnych i lokalnych są kluczem do skuteczności działań ochrony środowiska. W związku z powyższym ważną rolę w tym zakresie pełnią jednostki samorządu terytorialnego współdziałającego z administracją rządową (Barczak, 2006, s. 13). Ochrona środowiska w przestrzeni lokalnej polega na racjonalnym kształtowaniu stanu środowiska i gospodarowaniu jego zasobami oraz przeciwdziałaniu naruszaniu elementów stanu przyrodniczego. Lokalna polityka ekologiczna w Polsce prowadzona jest za pomocą gminnych programów ochrony środowiska oraz wydanych decyzji dotyczących środowiska naturalnego. Kompetencją gminy jest uchwalenie programu ochrony środowiska uwzględniającego cele zawarte w strategii, programach i dokumentach programowych. Z wykonania programu organ wykonawczy gminy sporządza co dwa lata raport, który przedstawia radzie gminy, a następnie przekazuje dokument organowi wykonawczemu powiatu (Ustawa, 6.03.2018, art. 18 ust. 2, ust. 3). Rada gminy ma uprawnienie do analizy i rozpatrywania informacji o stanie bezpieczeństwa w gminie i określania na tej podstawie kierunków dalszych działań w zakresie ochrony środowiska, bezpieczeństwa sanitarnego, 
bezpieczeństwa i porządku publicznego. Kompetencją organu wykonawczego, w przypadku powstania bezpośredniego zagrożenia, jest natomiast wydawanie poleceń służbom i inspekcjom dotyczących zagrożeń i usuwania ich skutków na terenie gminy. Rozwiązania te wydają się słuszne. Przyznawane zadania wynikają z uzasadnionych potrzeb państwa w odniesieniu do przestrzeni lokalnej. Samorząd gminny działając na podstawie ustawy o drogach publicznych, wykonuje zadania dotyczące dróg publicznych, przeciwdziała niekorzystnym przeobrażeniom środowiska, np. w następstwie budowy dróg, odpowiada za utrzymywanie zieleni przydrożnej (Ustawa z 13.09.1996, poz. 1454, 1629). Ponosi także odpowiedzialność za utrzymanie infrastruktury technicznej, służącej kształtowaniu bezpiecznego środowiska, utrzymania porządku i czystości. Zadania te realizuje w ramach zadań własnych, wynikających z ustawy z 13 września 1996 roku o utrzymaniu czystości i porządku w gminach między innymi przez: tworzenie warunków do wykonywania prac związanych z utrzymaniem czystości i porządku na terenie gminy; zapewnianie budowy, utrzymania i eksploatacji regionalnych instalacji do przetwarzania odpadów komunalnych; nadzorowanie gospodarowania odpadami komunalnymi; ustanawianie selektywnego zbierania odpadów komunalnych; prowadzenie działań informacyjnych i edukacyjnych w zakresie prawidłowego gospodarowania odpadami komunalnymi; znakowanie obszarów dotkniętych lub zagrożonych chorobą zakaźną zwierząt (Ustawa, 12.09.1996). Określone ustawą rodzaje zachowań odpowiadają funkcjom prawa ochrony środowiska: funkcji konserwatorskiej wyrażanej przez regulacje prawne służące zachowaniu środowiska w stanie niezmienionym; funkcji restytucyjnej realizowanej poprzez przywracanie elementów środowiska do stanu właściwego; funkcji prewencyjnej polegającej na przeciwdziałaniu zanieczyszczeniom, w tym tworzeniu przepisów pozwalających zapobiegać naruszeniom środowiska (Ciechanowicz-McLean, 2015, s. 18 ). W celu określenia zasad utrzymania czystości rada gminy, po zasięgnięciu opinii państwowego powiatowego inspektora sanitarnego, uchwala regulamin utrzymania czystości i porządku na terenie gminy, określa stawki opłat za gospodarowanie odpadami komunalnymi, termin, częstotliwość i tryb uiszczania opłat, harmonogram odbioru odpadów komunalnych oraz zasady segregacji odpadów. Stworzenie systemu postępowania z odpadami komunalnymi jest jednym z najważniejszych zadań gminy w zakresie ochrony środowiska. Regulacje ogólne dotyczące gospodarki odpadami zawierają ustalenie, by prowadzić ją w sposób zapewniający ochronę życia i zdrowia oraz środowiska oraz uniemożliwiający powodowanie zagrożenia dla wody, powietrza, gleby, roślin i zwierząt, jak i niekorzystnego wpływu dla miejsc o dużym znaczeniu kulturowym i przyrodniczym (Ustawa, 14.12.2012, poz. 21 i z 2017 poz. 2422). W konsekwencji, do 31 grudnia 2020 roku gminy są obowiązane osiągnąć określony ustawą poziom recyklingu, obejmujący przygotowania do ponownego użycia danych frakcji odpadów komunalnych. Ważnym elementem jest więc inwestowanie w wiedzę obywateli o rzeczywistych i potencjalnych zagrożeniach, jakie mogą wystąpić w sytuacji braku lub zaniechań działań ustawowych. Kształtowanie świadomości zagrożeń i gotowości do ich unikania winno odbywać się w miejscu zamieszkania czy też miejscu pracy. Kontrolowanie realizacji tychże zadań powinno wynikać z potrzeb użytkowników danej przestrzeni.

W zakresie ochrony przestrzeni lokalnej przed powodzią, w tym klęską żywiołową, zadania organowi wykonawczemu gminy wyznaczają także przepisy ustawowe. W rozumieniu przepisów ustawy o stanie klęski żywiołowej pomoc i ochrona mogą być skutecznie podjęte wyłącznie przy zastosowaniu nadzwyczajnych środków, we współpracy różnych organów i instytucji, jak również 
specjalistycznych służb i formacji. Zgodnie z regulacjami zawartymi w ustawie wójt (burmistrz, prezydent) kieruje działaniami prowadzonymi na obszarze gminy w celu zapobieżenia skutkom klęski żywiołowej lub ich usunięcia. W stanie klęski żywiołowej na terenie gminy realizowane są w trybie pilnym działania zapobiegające skutkom, bądź zmierzające do ich usunięcia, takie jak między innymi: wydawanie wiążących poleceń organom jednostek pomocniczych, kierownikom jednostek organizacyjnych gminy, kierownikom jednostek ochrony przeciwpożarowej funkcjonujących na terenie gminy; współdziałanie i wymiana informacji odnoszących się do zapobiegania skutkom klęski żywiołowej lub ich usuwania; wprowadzenie świadczeń osobistych i rzeczowych; niezwłoczne opublikowanie komunikatów związanych z działaniami na rzecz zapobieżenia skutkom klęski żywiołowej lub ich usunięcia (Ustawa, 15.09.2017). Uprawnienia burmistrza w ww. zakresie mogą zostać zawieszone w przypadku niezdolności do kierowania lub niewłaściwego kierowania działaniami realizowanymi w warunkach klęski żywiołowej.

W literaturze przedmiotu odnośnie do udziału gminy w sferze ochrony środowiska wskazywany jest podział zadań, czyli zadania o charakterze: organizacyjnym, bezpośrednio-wykonawczym, zobowiązująco-reglamentacyjnym, kontrolno-nadzorczym (Ciechanowicz-McLean, 2015, s. 17). Zadania należące do pierwszej grupy obejmują czynności oddziałujące na stan środowiska jako całości, bądź na poszczególne jego elementy i zawierają się zarówno w gminnych programach ochrony środowiska, jak i w gminnych planach gospodarki odpadami. Celem zadań bezpośrednio-wykonawczych jest organizacja życia społecznego przy zachowaniu równowagi środowiskowej. Ich zakres może dotyczyć zadań własnych bądź zleconych. Dwie ostatnie grupy zadań dotyczą respektowania ustaleń regulaminowych oraz nadzoru nad ich przebiegiem i kontroli osiąganych rezultatów.

\section{Podsumowanie}

Jednym z zadań własnych gminy określonych w ustawie o samorządzie gminnym jest zaspokajanie zbiorowych potrzeb wspólnoty, w tym w zakresie porządku publicznego i bezpieczeństwa obywateli. Jednym z głównych zadań własnych gminy jest ochrona środowiska. Priorytetowym celem działań gminy jest tworzenie bezpiecznego środowiska sprzyjającego aktywności społecznej. Przedstawione w artykule kwestie związane z ochroną środowiska realizowane przez samorząd gminny, pozwalają stwierdzić, że gminę obowiązuje szeroki zakres czynności. Analizowane regulacje prawne świadczą o uświadamianym projektowaniu zadań na rzecz ochrony środowiska. Polityka ekologiczna w Polsce po akcesji do Unii Europejskiej przyczyniła się do rozwiązań systemowych skierowanych do władz lokalnych i podmiotów gospodarczych odpowiedzialnych za stan środowiska oraz do obywateli. Polityka w zakresie ochrony środowiska uwzględnia zatem potrzeby społeczne uwarunkowane wzrostem zagrożeń środowiskowych.

Współcześnie rozwiązania wdrażane w systemach lokalnych ukierunkowane są na spójność i jednolitość postępowania, koordynowania działań i procedur, w szczególności obejmujących proces planowania, edukacji i upowszechniania wiedzy o sposobach zapobiegania degradacji stanu środowiska. Dążenie do dbałości o jakość środowiska wymaga ciągłego modernizowania. Tym bardziej, że kierunki edukacji ekologicznej określone zostały np. już w 1997 roku w Narodowej Strategii Edukacji Ekologicznej, a następnie w Konwencji „O Dostępie do 
Informacji, Udziale Społeczeństwa w Podejmowaniu Decyzji oraz Dostępie do Sprawiedliwości w Sprawach Dotyczących Środowiska”, tzw. Konwencja z Aarhus podpisana 25 czerwca 1998 roku w Danii, w czasie IV Paneuropejskiej Konferencji Ministrów Ochrony Środowiska m. in. przez Polskę.

Aktywność gminy na rzecz ochrony środowiska może w znacznym stopniu przyczyniać się do budowania fundamentu poczucia bezpieczeństwa w aspekcie społecznym, gospodarczym i przyrodniczym. Konieczne jest jednak podjęcie działań służących podnoszeniu świadomości ekologicznej jako specyficznej wiedzy o zagrożeniach i ochronie środowiska oraz o instrumentach gospodarowania jego zasobami.

\section{Bibliografia}

\section{Akty prawne}

Konstytucja Rzeczypospolitej Polskiej z 2.04.1997 r. (Dz. U. 1997 nr 78 poz. 483).

Ustawa z 13.04.2018 r. Prawo ochrony środowiska (t.j. Dz. U. z 2018 r., poz. 799).

Ustawa z 21.03.1985 r. o drogach publicznych (t.j. Dz. U z 2018 r., poz. 2068 ze zm.).

Ustawa z 13.09.1996 r. o utrzymaniu czystości i porządku w gminach (t.j. Dz. U. z 2018 r. poz. 1454,1629).

Ustawa z 14.12.2012 r. o odpadach (Dz. U. z 2018 r. poz. 21 i z 2017 poz. 2422).

Ustawa o stanie klęski żywiołowej z 15.09.2017 r. (t.j. Dz. U z 2017 r., poz. 1897).

Ustawa z 6.03.2018 r. o ochronie przeciwpożarowej (Dz. U. z 2018 r., poz. 620).

Ustawa z dnia 27 kwietnia 2001 r. Prawo ochrony środowiska. (Dz.U. $2001 \mathrm{nr} 62$ poz. 627.)

Deklaracja Sztokholmska, Uchwała Konferencji Sztokholmskiej z 14.06.1972 r. dotycząca naturalnego środowiska człowieka. Pobrane z: http://www.wolfpunk.most.org.pl/deksztok.htm (16.11.2019).

\section{Literatura}

Barczak, A. (2006). Zadnia samorządu terytorialnego w zakresie ochrony środowiska. Warszawa: Dom Wydawniczy $\mathrm{ABC}$.

Borkowski, R. (2017). Teoretyczno-metodologiczne aspekty rozważań nad bezpieczeństwem ekologicznym. W: M. Kubiak, M. Lipińska- Rzeszutek (red.), Współczesne bezpieczeństwo ekologiczne (s. 17-38). WarszawaSiedlce: Instytut Nauk Społecznych i Bezpieczeństwa Wydział Humanistyczny Uniwersytet Przyrodniczo-Humanistyczny w Siedlcach.

Bylicki, L. (2014). Ochrona środowiska w Unii Europejskiej. Zeszyty Naukowe PWSZ w Płocku, 20. $185-199$.

Ciechanowicz-McLean, J. (2015). Prawo ochrony i zarzadzania środowiskiem. Warszawa: Wydawnictwo Difin.

Ciszek, M. (2017). Filozofia postrzegania problemu ochrony środowiska naturalnego (bezpieczeństwa ekologicznego) w Strategii Bezpieczeństwa Narodowego Rzeczypospolitej Polskiej z 2014 roku. W: M. Kubiak, M. Lipińska-Rzeszutek (red.), Współczesne bezpieczeństwo ekologiczne (s. 115-144). Warszawa-Siedlce: Instytut Nauk Społecznych i Bezpieczeństwa Wydział Humanistyczny Uniwersytet Przyrodniczo-Humanistyczny w Siedlcach.

http://seib.uksw.edu.pl/sites/default/files/leszek_karski_znaczenie_prawa_ochrony_srodowiska.pdf (17.11.2019).

Karski, L. (2011). Znaczenie prawa ochrony środowiska. Studia Ecologiae et Bioethicae UKSW, 1 (9), 85-97. 
Kasperek, T. (2014). Bezpieczeństwo wewnętrzne kraju w kontekście zagrożeń ekologicznych Morza Bałtyckiego. W: M. Będżmirowski, J. Zawadzki (red.), Holistyczna ocena bezpieczeństwa-aspekt współczesny (s. 67-86). Warszawa: Wyższa Szkoła Bankowa w Gdańsku.

Mieteń, M. (2014). Współczesne bezpieczeństwo i jego rodzaje. W: P. Szmitkowski (red.), Wybrane aspekty wspótczesnego bezpieczeństwa i jego zagrożeń (s. 31-46.), Siedlce: Wydawnictwo Uniwersytetu Przyrodniczo-Humanistycznego w Siedlcach.

Stawarska, R. (2001). Wybrane efekty członkostwa Polski w Unii Europejskiej w perspektywie makro- i mikroekonomicznej. Studia Europejskie, 1, 95-122.

Szela, I. (2013). Ochrona porządku i bezpieczeństwa publicznego jako zadanie własne samorządu lokalnego. Kwartalnik Naukowy OAP UW e-Politikon, 6, 162-186.

Ura, E. (2003). Realizacja przez samorząd gminny zadań w zakresie ochrony bezpieczeństwa i porządku publicznego. W: E Ura (red.), Bezpieczeństwo i porządek publiczny - historia, teoria, praktyka. Rzeszów: Wydawnictwo Politechniki Rzeszowskiej. 